
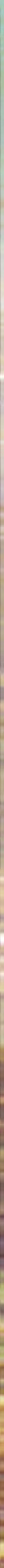

\title{
$2=$
}

U.S. DEPARTMENT OF THE INTERIOR

U.S. GEOLOGICAL SURVEY

3) Water-Quality Data for

3. Walnut Canyon and Wupatki

National Monuments, Arizona2001-02

Open-File Report 03-286

Prepared in cooperation with the NATIONAL PARK SERVICE
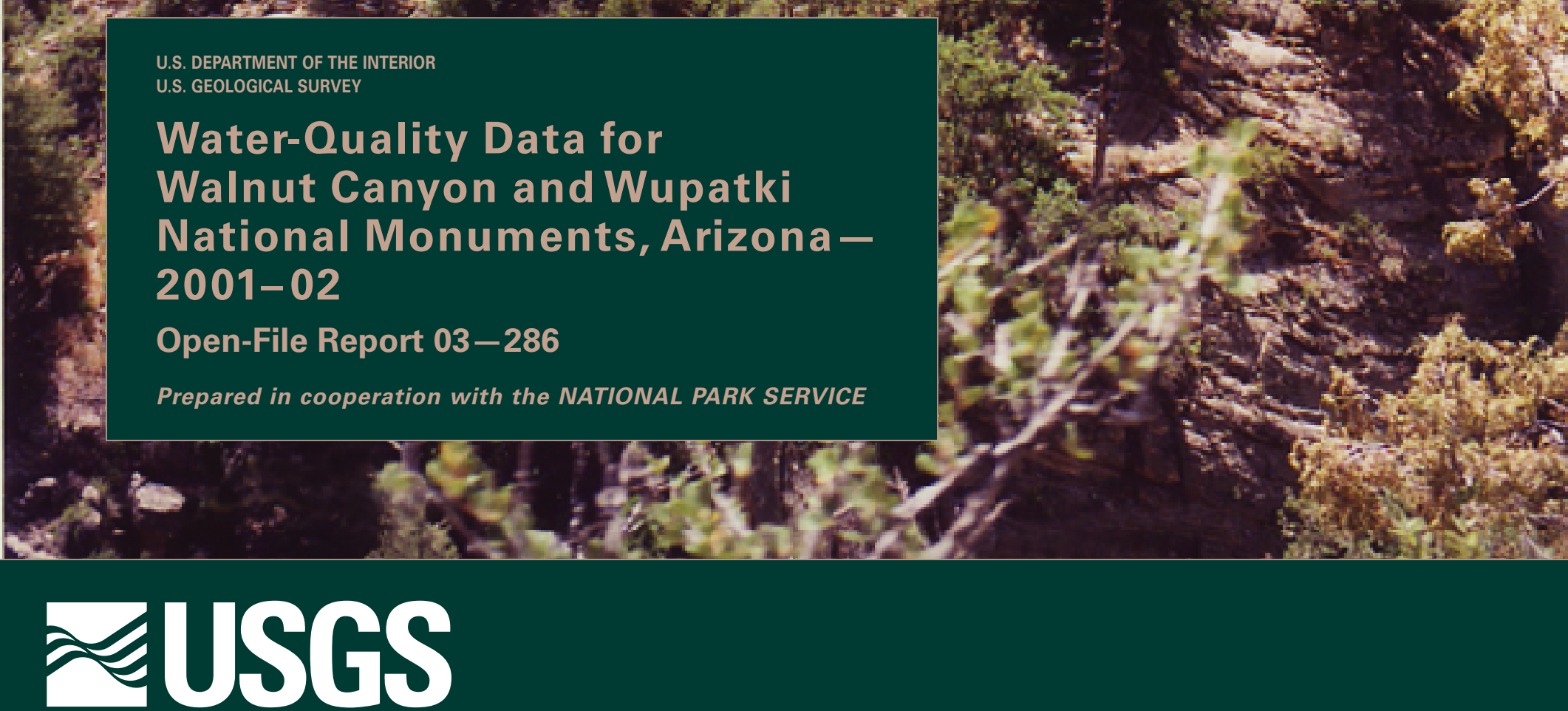
The front cover photograph of Walnut Canyon National Monument has been digitally altered. 


\section{Water-Quality Data for Walnut Canyon and Wupatki National Monuments, Arizona-2001-02}

Open-File Report 03-286

Prepared in cooperation with the NATIONAL PARK SERVICE 


\section{U.S. DEPARTMENT OF THE INTERIOR \\ GALE A. NORTON, Secretary}

U.S. GEOLOGICAL SURVEY

Charles G. Groat, Director

The use of firm, trade, and brand names in this report is for identification purposes only and does not constitute endorsement by the U.S. Geological Survey.

For additional information write to:

District Chief

U.S. Geological Survey

Water Resources Division

520 N. Park Avenue, Suite 221

Tucson, AZ 85719-5035
Copies of this report can be purchased from:

U.S. Geological Survey

Information Services

Box 25286

Federal Center

Denver, C0 80225-0046

Information about U.S. Geological Survey programs in Arizona is available online at http://az.water.usgs.gov. 


\section{CONTENTS}

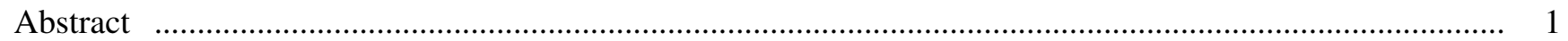

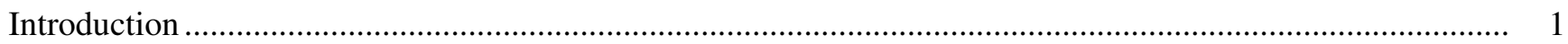

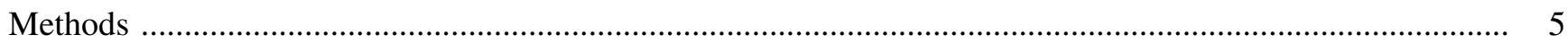

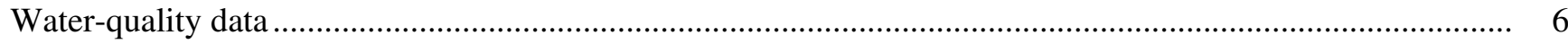

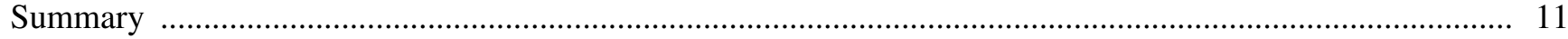

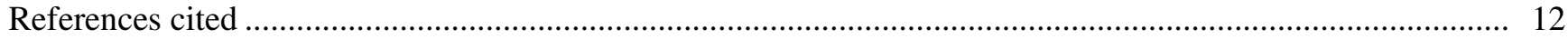

\section{FIGURES}

1. Map showing locations of Walnut Canyon and Wupatki National Monuments and water-quality data-collection sites.

\section{TABLES}

1. Location, altitude, and hydrologic characteristics of water-quality data-collection sites, Walnut Canyon and Wupatki National Monuments, Arizona, 2001-02

2. Field measurements, and concentrations of major ions, nutrients, trace elements, uranium, and organic compounds in water from selected sites, Walnut Canyon and Wupatki National Monuments, Arizona, 2001-02

3. U.S. Environmental Protection Agency Primary and Secondary Maximum Contaminant Levels for analyzed constituents in water samples from selected sites, Walnut Canyon and Wupatki National Monuments, Arizona, 2001-02 10

4. Discharge at selected sites, Walnut Canyon and Wupatki National Monuments, Arizona, 2001-02 .... 11

\section{CONVERSION FACTORS AND DATUMS}

\begin{tabular}{lcl}
\hline Multiply & \multicolumn{1}{c}{ By } & To obtain \\
\hline inch (in) & 2.54 & centimeter \\
inch (in) & 25.4 & millimeter \\
foot (ft) & 0.3048 & meter \\
mile $(\mathrm{mi})$ & 1.609 & kilometer \\
square mile $\left(\mathrm{mi}^{2}\right)$ & 2.590 & square kilometer \\
acre-foot $(\mathrm{acre}-\mathrm{ft})$ & 0.001233 & cubic hectometer \\
cubic foot per second $\left(\mathrm{ft}^{3} / \mathrm{s}\right)$ & 0.02832 & cubic meter per second \\
gallon per minute $(\mathrm{gal} / \mathrm{min})$ & 0.06309 & liter per second \\
gallon per day $(\mathrm{gal} / \mathrm{d})$ & 0.003785 & cubic meter per day \\
\hline
\end{tabular}


Temperature in degrees Celsius $\left({ }^{\circ} \mathrm{C}\right)$ may be converted to degrees Fahrenheit $\left({ }^{\circ} \mathrm{F}\right)$ as follows:

$$
{ }^{\circ} \mathrm{F}=\left(1.8^{\circ} \mathrm{C}\right)+32
$$

Vertical coordinate information is referenced to the National Geodetic Vertical Datum of 1929 (NGVD 29)—a geodetic datum derived from a general adjustment of the first-order level nets of both the United States and Canada, formerly called Sea Level Datum of 1929; horizontal coordinate information is referenced to the North American Datum of 1927 (NAD 27). Altitude, as used in this report, refers to distance above or below NGVD 29.

\section{ABBREVIATED WATER-QUALITY UNITS}

Chemical concentration and water temperature are given only in metric units. Chemical concentration in water is given in milligrams per liter $(\mathrm{mg} / \mathrm{L})$ or micrograms per liter $(\mu \mathrm{g} / \mathrm{L})$. Milligrams per liter is a unit expressing the solute mass (milligrams) per unit volume (liter) of water. One thousand micrograms per liter is equivalent to 1 milligram per liter. For concentrations lower than 7,000 milligrams per liter, the numerical value is about the same as for concentrations in parts per million. Specific conductance is given in microsiemens per centimeter at 25 degrees Celsius $\left(\mu \mathrm{S} / \mathrm{cm}\right.$ at $\left.25^{\circ} \mathrm{C}\right)$. 


\title{
Water-Quality Data for Walnut Canyon and Wupatki National Monuments, Arizona-2001-02
}

\author{
By Blakemore E. Thomas
}

\begin{abstract}
Water-quality data are provided for four sites in Walnut Canyon and Wupatki National Monuments in north-central Arizona. These data describe the current water quality and provide baseline water-quality information for monitoring future trends.

Water samples were collected from a ground-water seep and well in Walnut Canyon and from a spring and a river in Wupatki during September 2001 to September 2002. Water from the four sites is from four different sources. In Walnut Canyon, Cherry Canyon seep is in a shallow local aquifer, and the headquarters well is in a deep regional aquifer. In Wupatki, Heiser Spring is in a shallow local aquifer, and the Little Colorado River contains ground-water discharge from several aquifers and runoff from a 22,000 square-mile drainage area.

Concentrations of dissolved solids were similar within the two monuments; the range for water samples from Walnut Canyon was 203 to 248 milligrams per liter, and the range for water samples from Wupatki was 503 to 614 milligrams per liter. Concentrations of trace elements were generally low in water samples from the three ground-water sites-Cherry Canyon seep, Walnut Canyon headquarters well, and Heiser Spring. The water sample collected from the Little Colorado River, however, had high concentrations of aluminum (4,020 micrograms per liter), antimony (54 micrograms per liter), arsenic (14.3 micrograms per liter), and iron (749 micrograms per liter) relative to U.S. Environmental Protection Agency Primary and Secondary Maximum Contaminant Levels.

Concentrations of nitrate (as nitrogen) in water samples from the four sites were generally low ( 0.11 to 1.8 milligrams per liter) and are within the upper 25 percent of nitrate concentrations measured in the regional aquifer near Flagstaff in 1996 and 1997. Water samples from Cherry Canyon seep, Heiser Spring, and the Little Colorado River contained total coliform bacteria. Fecal coliform and Escherichia coli bacteria were found in water samples from Cherry Canyon seep and the Little Colorado River.

\section{INTRODUCTION}

In 1992, the National Park Service established a nationwide Level 1 Water Quality Inventory and Monitoring Program to obtain baseline water-quality information and to assess possible water-quality problems in national parks and monuments throughout the United States. Key water bodies are identified that

are essential to the cultural, historical, or natural resource management themes or that provide habitats for threatened or endangered plants and animals. The basic chemical character and possible waterquality problems of the water bodies are described through the collection and analysis of water samples and assessment of the chemical data. In 2001, the U.S. Geological Survey (USGS), in cooperation with the
\end{abstract}


National Park Service, began studies of Navajo, Walnut Canyon, and Wupatki National Monuments in northern Arizona as part of this Level 1 program. This report describes results of a water-quality inventory of Walnut Canyon and Wupatki National Monuments.

Walnut Canyon and Wupatki National Monuments are near Flagstaff in north-central Arizona (fig. 1). Walnut Canyon, established in 1915, is about 7 miles east of Flagstaff, and Wupatki, established in 1924, is about 30 miles northeast of Flagstaff. The purpose of both monuments is to protect and preserve the natural resources and ancient Indian ruins that were occupied from about 1100 to 1220 . The water resources of the monuments are used for public drinking-water supply and to support the natural plant and animal populations. Monument employees have a need for a better understanding of the quality of water resources for effective and informed management of visitor use and natural-resource protection. Although some waterquality data are available for the public-supply wells in each monument, little is known about the quality of the surface- and ground-water resources in the other areas of the monuments.

The objectives of this water-quality inventory of Walnut Canyon and Wupatki National Monuments were to identify key water bodies, to describe the current water-quality conditions, and to assess possible water-quality problems. Water samples were collected from four sites during September 2001 to September 2002. These samples were analyzed for general chemical characteristics and constituents that can be indicators of water-quality problems.

Walnut Canyon National Monument is $5 \mathrm{mi}^{2}$ and ranges in altitude from 6,200 to $6,900 \mathrm{ft}$. Walnut Canyon is deeply incised into horizontal layers of sandstone and limestone to depths of 250 to $400 \mathrm{ft}$. Wupatki National Monument is $55 \mathrm{mi}^{2}$ and ranges in altitude from 4,300 to 5,700 ft. Wupatki is mostly on gently sloping sedimentary rocks; volcanic rocks are exposed at the higher altitudes along the western boundary. The Little Colorado River is at the lowest altitude of the monument at the eastern boundary.

The general area of the monuments has a variable climate with arid to semi-arid conditions. Precipitation falls mostly as snow in the winter in the higher altitudes and as rain in all altitudes during the other seasons. The monument headquarters at Walnut Canyon is at an altitude of $6,700 \mathrm{ft}$ and has an average annual precipitation of about 20 inches. The monument headquarters at Wupatki is at an altitude of $4,900 \mathrm{ft}$ and has an average annual precipitation of about 8 inches (table 1; U.S. Department of Agriculture, 1999; Western Regional Climate Center, Desert Research Institute, 2002). The large difference in precipitation between Walnut Canyon and Wupatki is caused by an orographic rain shadow from the San Francisco Mountains southwest of Wupatki and the difference in altitude of the two areas. Precipitation is spread fairly evenly throughout the year at Walnut Canyon. Most of the precipitation (40 percent) at Wupatki falls during the summer. Frontal storms move through the area in the fall, winter, and spring; thunderstorms are common in the summer. The north-facing slopes of Walnut Canyon have mostly douglas fir and gambel oak trees, and the south-facing slopes have mostly piñon and juniper trees. Wupatki has mostly juniper savanna and grassland in the higher altitudes and greasewood and sagebrush in the lower altitudes.

Important water bodies in the monuments include ground water, springs, and streams. Ground water is the source of drinking water for monument employees and visitors. Springs and streams provide water and habitat for plants and animals.

Four key water bodies or sample sites were identified in Walnut Canyon and Wupatki National Monuments (table 1 and fig. 1):

1. Cherry Canyon seep near lower Walnut Canyon,

2. Walnut Canyon headquarters well,

3. Heiser Spring in Wupatki National Monument, and

4. Little Colorado River along the eastern border of Wupatki National Monument.

There are two important aquifers underlying Walnut Canyon (Bills and others, 2000). A shallow perched aquifer in the Kaibab Formation and upper part of the Coconino Sandstone is recharged locally and discharges water to several springs or seeps near the bottoms of Walnut Canyon and some tributary canyons. A regional aquifer in the Coconino Sandstone, Schnebly Hill Formation, and Supai Group is the source of water for most uses in the Flagstaff and Walnut Canyon areas. Depth to the water table in the regional aquifer is about $1,500 \mathrm{ft}$ below land surface in the Walnut Canyon area (Bills and others, 2000). 


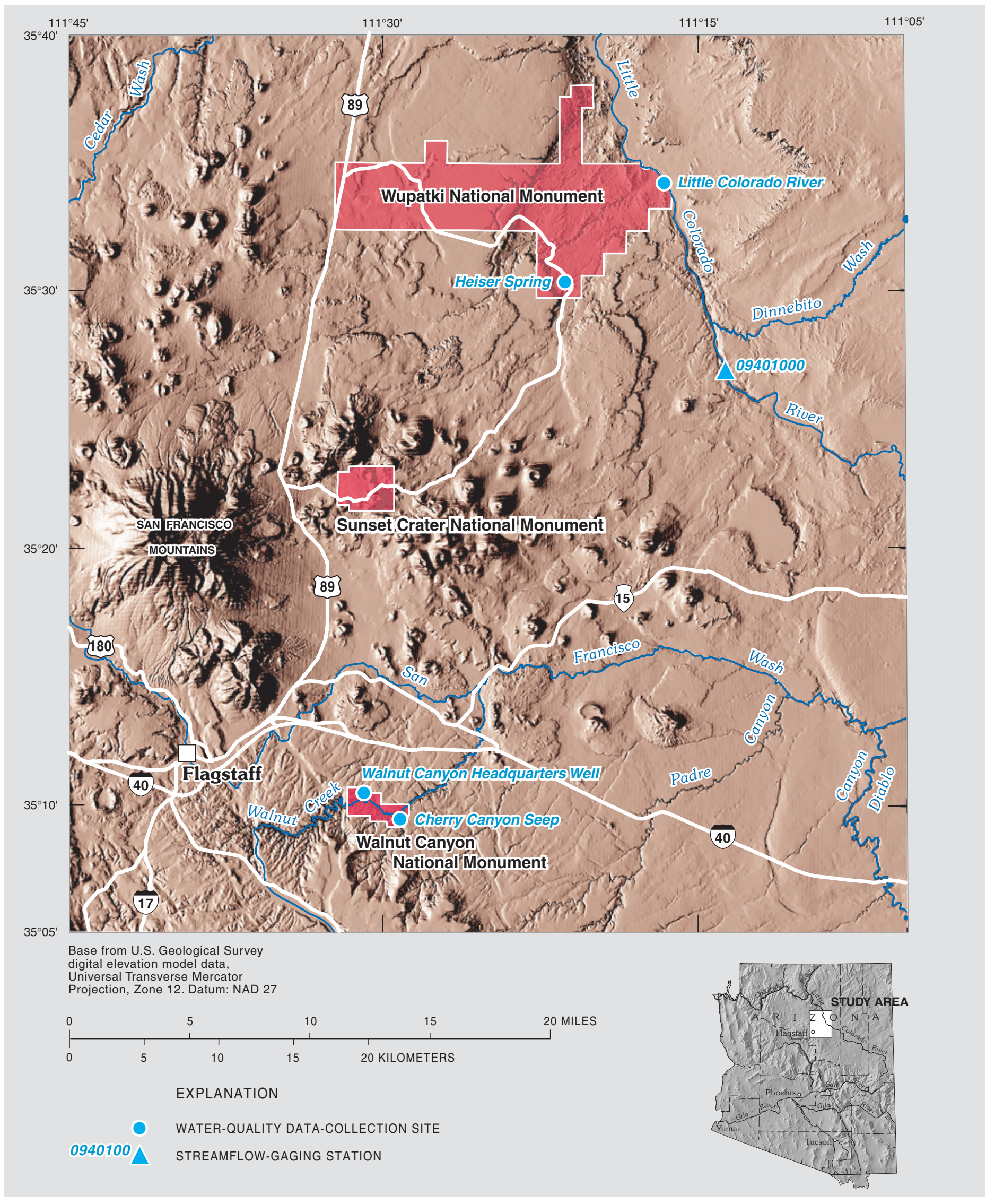

Figure 1. Locations of Walnut Canyon and Wupatki National Monuments and water-quality data-collection sites. 
Table 1. Location, altitude, and hydrologic characteristics of water-quality data-collection sites, Walnut Canyon and Wupatki National Monuments, Arizona, 2001-02

[N/A, not applicable]

\begin{tabular}{|c|c|c|c|c|c|c|c|}
\hline Site name & $\begin{array}{c}\text { National } \\
\text { Monument }\end{array}$ & Latitude & Longitude & $\begin{array}{l}\text { Land-surface } \\
\text { altitude, in } \\
\text { feet above } \\
\text { sea level }\end{array}$ & $\begin{array}{l}\text { Well depth, } \\
\text { in feet } \\
\text { below land } \\
\text { surface }\end{array}$ & $\begin{array}{l}\text { Aquifer and rock } \\
\text { formations }\end{array}$ & Use of water \\
\hline $\begin{array}{l}\text { Cherry Canyon } \\
\text { Seep }\end{array}$ & $\begin{array}{l}\text { Walnut } \\
\text { Canyon }\end{array}$ & 350923 & 1112854 & 6,300 & N/A & $\begin{array}{l}\text { Perched aquifer in } \\
\text { Kaibab Formation } \\
\text { or upper Coconino } \\
\text { Sandstone }^{1}\end{array}$ & Plants and animals \\
\hline $\begin{array}{l}\text { Walnut Canyon } \\
\text { headquarters } \\
\text { well }\end{array}$ & $\begin{array}{l}\text { Walnut } \\
\text { Canyon }\end{array}$ & 351025 & 1113037 & 6,710 & 2,007 & $\begin{array}{l}\text { Regional aquifer } \\
\text { (well completed in } \\
\text { the Supai Group) }{ }^{1}\end{array}$ & Public supply \\
\hline Heiser Spring & Wupatki & 353021 & 1112114 & 4,850 & N/A & $\begin{array}{l}\text { Local aquifer in } \\
\text { Moenkopi } \\
\text { Formation }^{2}\end{array}$ & Plants and animals \\
\hline $\begin{array}{l}\text { Little Colorado } \\
\text { River }\end{array}$ & Wupatki & 353413 & 1111627 & 4,295 & N/A & N/A & $\begin{array}{l}\text { Plants and animals (at } \\
\text { monument boundary) }\end{array}$ \\
\hline
\end{tabular}

${ }^{1}$ Bills and others, 2000.

${ }^{2}$ Cosner, 1962.

Cherry Canyon seep and the Walnut Canyon headquarters well were selected for water-quality samples in Walnut Canyon. Cherry Canyon seep is in Cherry Canyon about $400 \mathrm{ft}$ upstream from the confluence with Walnut Canyon (fig. 1). The seep is in the shallow perched aquifer, and it is an important source of water for plants and animals in the monument. The Walnut Canyon headquarters well is about $800 \mathrm{ft}$ northwest of the headquarters building. It yields water from the regional aquifer that is used as the drinking-water supply for monument employees and visitors.

The surface-water flow system in Walnut Canyon has been severely altered by two dams; the closest dam is about 10 miles upstream from the monument. Walnut Creek flows through the bottom of Walnut Canyon and has a drainage area of about $170 \mathrm{mi}^{2}$ at the upstream boundary of the monument. The two dams on Walnut Creek upstream from the monument have effectively stopped all flows, except for some overflow from large floods that fill up the impounded lakes. There are occasional small flows down the side canyons from snowmelt or rainfall runoff. Flow in Walnut Creek, therefore, is not an important part of the current water resources of the monument.

Important water bodies in Wupatki National Monument are the Little Colorado River, ephemeral streams, ground water, and springs. Heiser Spring and the Little Colorado River were selected for this inventory. Flow in ephemeral streams has helped create the topography of the monument, but the flows are too infrequent to be an important source of water for plants and animals.

Heiser Spring is in the southern part of the monument at an altitude of about 4,850 ft (table 1 and fig. 1). It discharges water from an aquifer in the Moenkopi Formation that consists of interbedded sandstone and shale (Cosner, 1962). The aquifer is recharged at higher land-surface altitudes to the west and southwest of the monument. Heiser Spring flows continuously at low rates throughout the year. The spring is developed into concrete spring boxes and was used in the past by Native American people and by wildlife. 
The Little Colorado River provides water and habitat for plants and animals on the eastern boundary of the monument. At the boundary, the Little Colorado River is at an altitude of about $4,300 \mathrm{ft}$ and has a drainage area of about 22,000 $\mathrm{mi}^{2}$ (table 1 and fig. 1). From 1925 to 1994, a streamflow-gaging station (Little Colorado River at Grand Falls, 0940100) was operated on the Little Colorado River about $10 \mathrm{mi}$ upstream from the monument boundary. Streamflow at that site is similar to streamflow at the boundary. Streamflow at Grand Falls is extremely variable. The average annual discharge is about $260 \mathrm{ft}^{3} / \mathrm{s}$ and the coefficient of variation (COV) of annual streamflow is about 0.8 . The COVs for monthly flows range from 1.0 to 4.0. The smallest COVs are for March-April, and the largest COVs are for May-June (Pope and others, 1998).

The primary threats to the water quality in Walnut Canyon are from sheep and cattle that graze on the south side of the canyon and from monument operations, such as maintenance shops and sewage lagoons (Paul Whitefield, Walnut Canyon and Wupatki National Monuments, written commun., 2001). Manure from the sheep and cattle and sewage from the sewage lagoon could cause nitrogen or bacteriological contamination. Materials used in shops or vehicles could cause hydrocarbon contamination. The vulnerable water resources are ephemeral streams or the shallow local aquifer. Contamination of the regional aquifer under Walnut Canyon is less likely because depths from land surface to ground water in the monument are about $1,500 \mathrm{ft}$; the travel path from the source to the water table is long and attenuation of the contaminant is likely (Fuhrer and others, 1999). In addition to the current threats, future threats could come from residential or commercial development of the Walnut Canyon watershed (Paul Whitefield, Walnut Canyon and Wupatki National Monuments, written commun., 2001).

The primary threats to the water quality of Heiser Spring in Wupatki National Monument are from sheep and cattle that graze in the recharge areas to the west and southwest of the monument (Paul Whitefield, Walnut Canyon and Wupatki National Monuments, written commun., 2001). The primary threats to water quality of the Little Colorado River in Wupatki come from a variety of sources in the large watershed. Cattle and sheep, sewage lagoons, or septic systems could cause nutrient or bacterial contamination. Mining activities could cause uranium, trace element, or hydrocarbon contamination (Graf and others, 1996). Agricultural activities could cause nutrient or pesticide contamination (Paul Whitefield, Walnut Canyon and Wupatki National Monuments, written commun., 2001).

The author acknowledges the cooperation and assistance of Paul Whitefield of Walnut Canyon and Wupatki National Monuments. Paul assisted with access to all the water-quality sites, and he was particularly helpful in a reconnaissance of Walnut Canyon and finding a suitable place to collect a water sample from Cherry Canyon seep.

\section{METHODS}

The current chemical character and water quality of the key water bodies of Walnut Canyon and Wupatki National Monuments were determined by collecting water samples and analyzing those samples for the following properties or constituents: (1) field measurements, (2) major ions, (3) nutrients, (4) trace elements, and (5) uranium. Concentrations of oil and grease and petroleum hydrocarbons were also determined in a water sample from the Walnut Canyon headquarters well. Field measurements are $\mathrm{pH}$, specific conductance, temperature, dissolved oxygen, alkalinity, fecal-indicator bacteria [total coliform, fecal coliform, and Escherichia coli (E. coli)], and discharge rates for springs.

Concentrations of bacteria and nitrogen were used to indicate whether manure from grazing animals has affected the water quality of the monuments. Concentrations of trace elements and uranium were used to assess possible effects of mining activities on water quality of the Little Colorado River. In addition to human or animal caused water-quality problems, some natural constituents can be harmful to human health when present at high concentrations (U.S. Environmental Protection Agency, 2002). These potentially harmful constituents include some of the major ions, most of the trace elements, and uranium. Concentrations of all the constituents were compared to current U.S. Environmental Protection Agency Primary and Secondary Maximum Contaminant Levels (U.S. Environmental Protection Agency, 2002).

Water samples were collected from Cherry Canyon seep and Heiser Spring in the fall of 2001 (SeptemberOctober) and spring of 2002 (May), and were analyzed to assess water quality, including seasonal variations. 
The flow from Cherry Canyon seep in May 2002 was small, so only a small amount of water could be collected, and only a limited chemical analysis of major ions and lab alkalinity could be performed. Only one water sample was collected from the Walnut Canyon headquarters well for a chemical analysis (in September 2001) because water quality in a deep regional aquifer typically has little to no seasonal variation. Recharge water that carries new dissolved constituents takes a long time to reach a deep aquifer, and there are many opportunities for attenuation of undesirable constituents in the recharge water (Fuhrer and others, 1999). A second water sample was collected from the headquarters well in October 2001 for analysis of bacteria because the incubator lost power during the analysis of the first sample collected in September. The original study workplan specified that two samples would be collected from the Little Colorado River to determine seasonal variation in water quality. During drought conditions in September 2001 to September 2002, however, the Little Colorado River flowed only for brief periods. The Little Colorado River at Wupatki National Monument only started flowing from thunderstorm runoff in late July 2002. Only one sample, therefore, was collected from the Little Colorado River (in September 2002).

Water samples were collected according to standard USGS protocols described in several USGS Techniques of Water-Resources Investigations Reports (Friedman and Erdmann, 1982; Britton and Greeson, 1988; Koterba and others, 1995; Wilde and others, 1998a,b,c; Wilde and Radtke, 1998; Myers and Wilde, 1999; and Wilde and others, 1999). All laboratory analyses of the water samples were conducted at the USGS National Water-Quality Laboratory (NWQL) according to techniques described in Fishman and Friedman (1989), Faires (1993), Fishman (1993), McLain (1993), Struzeski and others (1996); Jones and Garbarino (1998), and Garbarino (1999).

The water samples from the Walnut Canyon headquarters well were collected from a faucet near the wellhead and ahead of any water treatment such as disinfection, softening, or filtration. Polyethylene tubing was used to connect the faucet to a splitter that directed the water to a flow chamber, a filter line, a whole-water line, and a disposal or overflow line. Temperature, $\mathrm{pH}$, specific conductance, and dissolvedoxygen concentrations were measured by field instruments attached to the flow chamber. Field instruments were calibrated the day of the sampling trip. Water samples were collected from a filtration unit for analysis of dissolved constituents. Water samples were collected directly from the faucet for bacteriological analyses.

A depth-integrated dip sample (from a single point in the river) was collected from the Little Colorado River. Water temperature and dissolved oxygen were measured directly from the river, and $\mathrm{pH}$, specific conductance, and alkalinity were measured the same day at the laboratory in Flagstaff. All field instruments were calibrated the day of the sampling trip. Discharge in the Little Colorado River was not measured because the river was too deep to make the measurement safely.

Water samples from Cherry Canyon seep and Heiser Spring were collected as point (grab) samples. Water temperature was measured directly from the seep and spring, and $\mathrm{pH}$, specific conductance, and alkalinity were measured the same day at the laboratory in Flagstaff. All field instruments were calibrated the day of the sampling trip. Discharge from Cherry Canyon seep was too small to measure. Discharge from Heiser Spring could not be measured directly because all surface expression of the spring water is in a concrete box. To obtain a representative water-quality sample of the spring and to determine possible seasonal variations in discharge, water was pumped out of the spring box with a centrifugal pump until about 1 inch of water remained. The water level was allowed to recover as water flowed back into the box. After 140 minutes, water samples were collected and the rate of recovery was determined by measuring the volume of water that flowed back into the box.

All samples that were sent to the NWQL were processed and preserved as described in the appropriate protocols. Samples were passed through a 0.45 -micron filter for analysis of dissolved constituents (alkalinity, major ions, nutrients, trace elements, and uranium. Alkalinity was measured using electrometric procedures. Water samples for bacteriological analysis were collected and stored in sterile bottles prior to preparation for standard plate-count analysis.

\section{WATER-QUALITY DATA}

The four water-quality sites have four different water types. The water types are calcium bicarbonate for Cherry Canyon seep, calcium magnesium bicarbonate for the Walnut Canyon headquarters well, calcium sodium sulfate for Heiser Spring, and sodium 
bicarbonate for the Little Colorado River. Dissolvedsolids concentrations were similar within the two monuments; the range for water samples from Walnut Canyon was 203 to $248 \mathrm{mg} / \mathrm{L}$, and the range for water samples from Wupatki was 503 to $614 \mathrm{mg} / \mathrm{L}$ (table 2).

Concentrations of trace elements were generally low in water from the three ground-water sitesCherry Canyon seep, Walnut Canyon headquarters well, and Heiser Spring (table 2). The water sample collected from the Little Colorado River on September 13, however, had high concentrations of aluminum $(4,020 \mu \mathrm{g} / \mathrm{L})$, antimony $(54 \mu \mathrm{g} / \mathrm{L})$, arsenic $(14.3 \mu \mathrm{g} / \mathrm{L})$, and iron $(749 \mu \mathrm{g} / \mathrm{L})$. Water in the Little Colorado River is from runoff and ground-water discharge in the $22,000 \mathrm{mi}^{2}$ drainage area outside of the monument. The water sample in this study was collected during a period of high runoff from a large storm that lasted for several days. A USGS streamflow-gaging station on the Little Colorado River near Winslow (09400350; about 70 miles upstream of the sample site) recorded a maximum peak discharge of $20,100 \mathrm{ft}^{3} / \mathrm{s}$ on September 12 , and a daily mean discharge of $3,760 \mathrm{ft}^{3} / \mathrm{s}$ on September 13. A gaging station on the Little Colorado River near Cameron (09402000; about 35 miles downstream) recorded a maximum peak discharge of $11,500 \mathrm{ft}^{3} / \mathrm{s}$ on September 11, and a daily mean discharge of $1,850 \mathrm{ft}^{3} / \mathrm{s}$ on September 13 .

Concentrations of uranium were low in water from Cherry Canyon seep $(0.20 \mu \mathrm{g} / \mathrm{L})$ and from the Walnut Canyon headquarters well $(0.49 \mu \mathrm{g} / \mathrm{L})$. Concentrations of uranium were at moderate levels in the water samples from Wupatki; Heiser Spring had a concentration of $4.7 \mu \mathrm{g} / \mathrm{L}$ and the Little Colorado River had a concentration of $8.3 \mu \mathrm{g} / \mathrm{L}$.

Concentrations of nitrogen and bacteria were used as indicators of contamination from human or animal wastes (U.S. Geological Survey, 1999; U.S. Environmental Protection Agency, 2002). Nitrogen is naturally present in surface water and ground water, so the concentration has to be elevated above the natural concentration to indicate contamination. The natural concentration of nitrate in the water from the four sites is unknown. For reference, water samples collected from 24 wells or springs in the regional aquifer near Flagstaff in 1996 and 1997 had the following distribution of nitrate concentrations: median was 0.22 $\mathrm{mg} / \mathrm{L}, 75$ th percentile was $0.63 \mathrm{mg} / \mathrm{L}$, and maximum was $4.8 \mathrm{mg} / \mathrm{L}$ (Bills and others, 2000). Coliform bacteria are naturally present in the environment and feces, so the presence of total coliforms indicates only possible contamination. Fecal coliform and E. coli bacteria only come from human or animal fecal waste, so the presence of those bacteria indicates contamination from human or animal wastes (U. S. Environmental Protection Agency, 2002). At the Walnut Canyon Monument headquarters and visitor center, contamination from vehicles and the maintenance shop also was a concern, so analyses were made for oil and grease and petroleum hydrocarbons in the water sample from the monument headquarters well.

Concentrations of nitrate (as nitrogen) in water samples from the four sites were generally low ( 0.11 to $1.8 \mathrm{mg} / \mathrm{L}$ ) and are within the upper 25 percent of nitrate concentrations in the regional aquifer near Flagstaff in 1996 and 1997 (table 2). Water samples from Cherry Canyon seep, Heiser Spring, and the Little Colorado River contained total coliform bacteria. Fecal coliform and $E$. coli bacteria were found in water samples from Cherry Canyon seep and the Little Colorado River. Indicators of human or animal contamination were mixed at Heiser Spring; one sample in October 2001 contained fecal coliform and one sample in May 2002 did not contain fecal coliform or E. coli. Oil and grease and petroleum hydrocarbons were not found in the water sample from the Walnut Canyon headquarters well (table 2).

Concentrations of analyzed constituents in water samples from the four sites were compared to U.S. Environmental Protection Agency Primary and Secondary Maximum Contaminant Levels (U.S. Environmental Protection Agency, 2002; tables 2 and 3). Maximum Contaminant Levels (MCLs) for antimony and arsenic were exceeded in the water sample from the Little Colorado River. Several Secondary Maximum Contaminant Levels (SMCLs) were exceeded. The SMCLs for $\mathrm{pH}$ (range), dissolved solids, aluminum, and iron were exceeded in the sample from the Little Colorado River. The SMCLs for sulfate and dissolved solids were exceeded in the samples from Heiser Spring. The SMCL for manganese was exceeded in the sample from Cherry Canyon seep.

Water temperatures varied seasonally at Cherry Canyon seep and Heiser Spring; temperatures were warmer in the fall and cooler in the spring. Concentrations of major ions at the two sites had a small seasonal variation. Concentrations of 10 of the 17 trace element analytes in water from Heiser Spring were higher in May 2002 than in October 2001. 
Table 2. Field measurements, and concentrations of major ions, nutrients, trace elements, uranium, and organic compounds in water from selected sites, Walnut Canyon and Wupatki National Monuments, Arizona, 2001-02

$\left[{ }^{\circ} \mathrm{C}\right.$, degrees Celsius; $\mu \mathrm{S} / \mathrm{cm}$, microsiemens per centimeter at $25^{\circ} \mathrm{C} ; \mathrm{mg} / \mathrm{L}$, milligrams per liter; $\mu \mathrm{g} / \mathrm{L}$, micrograms per liter; $<$, less than; cols. per $100 \mathrm{~mL}$, colonies per 100 milliters; E. coli, Escherichia coli; e in front of bacteria concentration denotes estimated value; k after bacteria concentration denotes nonideal number of colonies on counting plate; dashes indicate no data]

\begin{tabular}{|c|c|c|c|c|c|c|}
\hline Site name & \multicolumn{2}{|c|}{$\begin{array}{l}\text { U.S. Geological Survey } \\
\text { identification number }\end{array}$} & Date of sample & $\begin{array}{c}\text { Specific } \\
\text { conductance, } \\
\text { field }(\mu \mathrm{S} / \mathrm{cm})\end{array}$ & pH, field (units) & $\begin{array}{c}\text { Water } \\
\text { temperature, } \\
\text { field }\left({ }^{\circ} \mathrm{C}\right)\end{array}$ \\
\hline \multirow[t]{2}{*}{ Cherry Canyon seep } & \multicolumn{2}{|c|}{350910111285201} & 09-18-01 & 446 & 7.3 & 16.0 \\
\hline & & & $05-02-02$ & ${ }^{1} 405$ & 7.4 & 8.8 \\
\hline Walnut Canyon headquarters well & \multicolumn{2}{|c|}{351025111303701} & 09-20-01 & 399 & 7.7 & 14.0 \\
\hline \multirow[t]{2}{*}{ Heiser Spring } & \multicolumn{2}{|c|}{353021111211401} & $10-23-01$ & 855 & 7.7 & 17.6 \\
\hline & & & $05-03-02$ & 856 & 7.9 & 13.5 \\
\hline Little Colorado River & \multicolumn{2}{|c|}{353413111162700} & $09-13-02$ & 614 & 8.7 & 19.3 \\
\hline Site name & $\begin{array}{l}\text { Date of } \\
\text { sample }\end{array}$ & $\begin{array}{c}\text { Oxygen, } \\
\text { dissolved, field } \\
\text { (mg/L) }\end{array}$ & $\begin{array}{c}\text { Calcium, } \\
\text { dissolved } \\
\text { (mg/L as Ca) }\end{array}$ & $\begin{array}{l}\text { Magnesium, } \\
\text { dissolved } \\
\text { (mg/L as } \mathrm{Mg})\end{array}$ & $\begin{array}{c}\text { Sodium, } \\
\text { dissolved } \\
\text { (mg/L as Na) }\end{array}$ & $\begin{array}{l}\text { Potassium, } \\
\text { dissolved } \\
\text { (mg/L as K) }\end{array}$ \\
\hline \multirow[t]{2}{*}{ Cherry Canyon seep } & $09-18-01$ & --- & 56.7 & 14.8 & 5.7 & 4.9 \\
\hline & $05-02-02$ & --- & 52.9 & 13.3 & 5.3 & 3.7 \\
\hline Walnut Canyon headquarters well & 09-20-01 & 8.3 & 43.4 & 24.7 & 4.4 & 0.97 \\
\hline \multirow[t]{2}{*}{ Heiser Spring } & $10-23-01$ & --- & 68.3 & 24.4 & 75.9 & 3.2 \\
\hline & $05-03-02$ & --- & 67.1 & 23.2 & 78.9 & 3.4 \\
\hline \multirow[t]{2}{*}{ Little Colorado River } & 09-13-02 & 8.7 & 3.9 & 1.2 & 129.3 & 2.1 \\
\hline & $\begin{array}{l}\text { Date of } \\
\text { sample }\end{array}$ & $\begin{array}{c}\text { Alkalinity, } \\
\text { dissolved, field } \\
\left(\mathrm{mg} / \mathrm{L} \text { as } \mathrm{CaCO}_{3}\right)\end{array}$ & $\begin{array}{l}\text { Bicarl } \\
\text { dissolv } \\
\text { (mg/L a }\end{array}$ & $\begin{array}{l}\text { onate, } \\
\text { d, field } \\
\left.\mathrm{HCO}_{3}\right)\end{array}$ & $\begin{array}{l}\text { arbonate, } \\
\text { olved, field } \\
\left.\text { g/L as } \mathrm{CO}_{3}\right)\end{array}$ & $\begin{array}{c}\text { Sulfate, } \\
\text { dissolved } \\
\left(\mathrm{mg} / \mathrm{L} \text { as } \mathrm{SO}_{4}\right)\end{array}$ \\
\hline \multirow[t]{2}{*}{ Cherry Canyon seep } & $09-18-01$ & 220 & 26 & & $<1$ & 2.0 \\
\hline & $05-02-02$ & ${ }^{1} 197$ & - & & --- & 1.4 \\
\hline Walnut Canyon headquarters well & $09-20-01$ & 203 & 24 & & $<1$ & 2.2 \\
\hline \multirow[t]{2}{*}{ Heiser Spring } & $10-23-01$ & 160 & 19 & & $<1$ & 261 \\
\hline & $05-03-02$ & 156 & 18 & & 1 & 268 \\
\hline Little Colorado River & 09-13-02 & ${ }^{1} 148$ & & & --- & 67.4 \\
\hline
\end{tabular}

\begin{tabular}{|c|c|c|c|c|c|c|}
\hline Site name & $\begin{array}{l}\text { Date of } \\
\text { sample }\end{array}$ & $\begin{array}{c}\text { Chloride, } \\
\text { dissolved (mg/L } \\
\text { as } \mathrm{CI} \text { ) }\end{array}$ & $\begin{array}{c}\text { Fluoride, } \\
\text { dissolved (mg/L } \\
\text { as F) }\end{array}$ & $\begin{array}{c}\text { Silica, } \\
\text { dissolved }(\mathrm{mg} / \mathrm{L} \\
\left.\text { as } \mathrm{SiO}_{2}\right)\end{array}$ & $\begin{array}{c}\text { Dissolved } \\
\text { solids, residue } \\
\text { at } 180^{\circ} \mathrm{C}(\mathrm{mg} / \mathrm{L})\end{array}$ & $\begin{array}{c}\text { Aluminum, } \\
\text { dissolved ( } \mu \mathrm{g} / \mathrm{L} \\
\text { as Al) }\end{array}$ \\
\hline \multirow[t]{2}{*}{ Cherry Canyon seep } & $09-18-01$ & 6.1 & $<0.2$ & 11.1 & 248 & 4 \\
\hline & $05-02-02$ & 6.4 & .1 & 10.5 & --- & --- \\
\hline Walnut Canyon headquarters well & 09-20-01 & 5.4 & $<.2$ & 10.5 & 203 & $<1$ \\
\hline \multirow[t]{2}{*}{ Heiser Spring } & $10-23-01$ & 10.0 & 1.2 & 20.2 & 584 & 2 \\
\hline & $05-03-02$ & 9.3 & 1.1 & 22.1 & 614 & 2 \\
\hline Little Colorado River & $09-13-02$ & 48.3 & 0.9 & 12.8 & 503 & 4,020 \\
\hline
\end{tabular}


Table 2. Field measurements, and concentrations of major ions, nutrients, trace elements, uranium, and organic compounds in water from selected sites, Walnut Canyon and Wupatki National Monuments, Arizona, 2001-02—Continued

\begin{tabular}{|c|c|c|c|c|c|c|c|c|c|}
\hline Site name & $\begin{array}{l}\text { Date of } \\
\text { sample }\end{array}$ & $\begin{array}{c}\text { Antimony, } \\
\text { dissolved } \\
\text { ( } \mu \mathrm{g} / \mathrm{L} \text { as } \mathrm{Sb})\end{array}$ & \multicolumn{2}{|c|}{$\begin{array}{c}\text { Arsenic, } \\
\text { dissolved, } \\
\text { ( } \mu \mathrm{g} / \mathrm{L} \text { as As) }\end{array}$} & \multicolumn{2}{|c|}{$\begin{array}{c}\text { Barium, } \\
\text { dissolved } \\
(\mu \mathrm{g} / \mathrm{L} \text { as } \mathrm{Ba})\end{array}$} & & $\begin{array}{l}\text { 3eryllium, } \\
\text { dissolved } \\
\mathrm{g} / \mathrm{L} \text { as } \mathrm{Be})\end{array}$ & $\begin{array}{c}\text { Boron, } \\
\text { dissolved } \\
(\mu \mathrm{g} / \mathrm{L} \text { as } \mathrm{B})\end{array}$ \\
\hline \multirow[t]{2}{*}{ Cherry Canyon seep } & $09-18-01$ & 0.12 & \multicolumn{2}{|l|}{1.6} & \multicolumn{2}{|r|}{60} & & $<.06$ & 30 \\
\hline & $05-02-02$ & --- & \multicolumn{2}{|l|}{---} & \multicolumn{2}{|r|}{---} & & --- & 40 \\
\hline Walnut Canyon headquarters well & 09-20-01 & $<.05$ & \multicolumn{2}{|l|}{.4} & \multicolumn{2}{|r|}{246} & & $<.06$ & $<10$ \\
\hline \multirow[t]{2}{*}{ Heiser Spring } & $10-23-01$ & $<.05$ & \multicolumn{2}{|l|}{1.2} & \multicolumn{2}{|r|}{11} & & $<.06$ & 130 \\
\hline & $05-03-02$ & .06 & \multicolumn{2}{|l|}{1.6} & \multicolumn{2}{|r|}{17} & & $<.06$ & 140 \\
\hline \multirow[t]{2}{*}{ Little Colorado River } & $09-13-02$ & 54 & \multicolumn{2}{|l|}{14.3} & \multicolumn{2}{|r|}{14} & & .09 & 422 \\
\hline & $\begin{array}{l}\text { Date of } \\
\text { sample }\end{array}$ & $\begin{array}{c}\text { Cadmium, } \\
\text { dissolved } \\
(\mu \mathrm{g} / \mathrm{L} \text { as Cd) }\end{array}$ & \multicolumn{2}{|c|}{$\begin{array}{c}\text { Chromium, } \\
\text { dissolved } \\
\text { ( } \mu \mathrm{g} / \mathrm{L} \text { as } \mathrm{Cr} \text { ) }\end{array}$} & \multicolumn{2}{|c|}{$\begin{array}{c}\text { Cobalt, } \\
\text { dissolved } \\
(\mu \mathrm{g} / \mathrm{L} \text { as Co })\end{array}$} & & $\begin{array}{l}\text { Copper, } \\
\text { lissolved } \\
\text { g/L as } \mathrm{Cu})\end{array}$ & $\begin{array}{c}\text { Iron, } \\
\text { dissolved } \\
(\mu \mathrm{g} / \mathrm{L} \text { as Fe })\end{array}$ \\
\hline \multirow[t]{2}{*}{ Cherry Canyon seep } & $09-18-01$ & $<.04$ & \multicolumn{2}{|l|}{13.5} & \multicolumn{2}{|r|}{1.0} & & 1.9 & 64 \\
\hline & $05-02-02$ & --- & \multicolumn{2}{|l|}{---} & \multicolumn{2}{|r|}{---} & & --- & 86 \\
\hline Walnut Canyon headquarters well & 09-20-01 & .05 & \multicolumn{2}{|l|}{$<.8$} & \multicolumn{2}{|r|}{.05} & & .7 & $<10$ \\
\hline \multirow[t]{2}{*}{ Heiser Spring } & $10-23-01$ & $<.04$ & 1.2 & & & .13 & & 1.0 & $<10$ \\
\hline & $05-03-02$ & $<.04$ & 4.7 & & & 4.7 & & 1.3 & $<10$ \\
\hline Little Colorado River & $09-13-02$ & .04 & 1.1 & & & 8.0 & & 14.9 & 749 \\
\hline Site name & $\begin{array}{l}\text { Date of } \\
\text { sample }\end{array}$ & $\begin{array}{c}\text { Lead, } \\
\text { dissolved } \\
(\mu \mathrm{g} / \mathrm{L} \text { as } \mathrm{Pb})\end{array}$ & $\begin{array}{r}\text { Mangan } \\
\text { dissolv } \\
(\mu \mathrm{g} / \mathrm{L} \text { as }\end{array}$ & & $\begin{array}{r}\text { Moly } \\
\text { dis } \\
(\mu \mathrm{g} /\end{array}$ & $\begin{array}{l}\text { Iybdenum, } \\
\text { issolved } \\
\text { /L as Mo) }\end{array}$ & & $\begin{array}{l}\text { Nickel, } \\
\text { lissolved } \\
\text { ig/L as } \mathrm{Ni} \text { ) }\end{array}$ & $\begin{array}{c}\text { Silver, } \\
\text { dissolved } \\
(\mu \mathrm{g} / \mathrm{L} \text { as } \mathrm{Ag})\end{array}$ \\
\hline Cherry Canyon seep & $09-18-01$ & 0.14 & 123 & & & .3 & & .95 & $<1$ \\
\hline & $05-02-02$ & --- & --- & & & --- & & --- & --- \\
\hline Walnut Canyon headquarters well & 09-20-01 & .43 & .5 & & & $<.2$ & & $<.06$ & $<1$ \\
\hline Heiser Spring & $10-23-01$ & .10 & 2.2 & & & 7.9 & & $<.06$ & $<1$ \\
\hline & $05-03-02$ & $<.08$ & 3.5 & & & 7.5 & & .15 & $<1$ \\
\hline Little Colorado River & 09-13-02 & .84 & 29.7 & & & 9.8 & & 2.6 & $<1$ \\
\hline Site name & $\begin{array}{l}\text { Date of } \\
\text { sample }\end{array}$ & $\begin{array}{c}\text { Zinc, } \\
\text { dissolved } \\
(\mu \mathrm{g} / \mathrm{L} \text { as } \mathrm{Zn})\end{array}$ & $\begin{array}{r}\text { Uranium, } \mathbf{n e} \\
\text { dissolv } \\
(\mu \mathrm{g} / \mathrm{L} \text { as }\end{array}$ & $\begin{array}{l}\text { tural, } \\
\text { ed } \\
\text { U) }\end{array}$ & $\begin{array}{r}\text { Oil an } \\
\text { tota }\end{array}$ & $\begin{array}{l}\text { Ind grease, } \\
\text { tal (mg/L) }\end{array}$ & $\begin{array}{r}\text { Pe } \\
\text { hydr } \\
\text { tot }\end{array}$ & $\begin{array}{l}\text { etroleum } \\
\text { |rocarbons, } \\
\text { tal (mg/L) }\end{array}$ & $\begin{array}{c}\text { Coliform, } \\
\text { total (cols. } \\
\text { per } 100 \mathrm{~mL} \text { ) }\end{array}$ \\
\hline Cherry Canyon seep & $09-18-01$ & 3 & .20 & & & --- & & --- & $>8,000$ \\
\hline & $05-02-02$ & --- & --- & & & --- & & --- & --- \\
\hline Walnut Canyon headquarters well & 09-20-01 & 328 & .49 & & & $<7$ & & $<2$ & $<1$ \\
\hline Heiser Spring & $10-23-01$ & 8 & 4.7 & & & --- & & --- & $\mathrm{e} 1,300$ \\
\hline & $05-03-02$ & 3 & 4.7 & & & --- & & --- & $>8,000$ \\
\hline Little Colorado River & $09-13-02$ & 5.3 & 8.3 & & & --- & & --- & $\mathrm{e} 70,000 \mathrm{k}$ \\
\hline Site name & $\begin{array}{l}\text { Date of } \\
\text { sample }\end{array}$ & $\begin{array}{c}\text { Coliform, } \\
\text { fecal (cols. } \\
\text { per } 100 \mathrm{~mL} \text { ) }\end{array}$ & $\begin{array}{l}\text { E. coli (cols. } \\
\text { per } 100 \mathrm{~mL})\end{array}$ & $\begin{array}{r}\text { Nitro } \\
\text { nitr } \\
\text { disso } \\
\text { (mg/L }\end{array}$ & $\begin{array}{l}\text { gen, } \\
\text { ite, } \\
\text { lved } \\
\text { as } N \text { ) }\end{array}$ & $\begin{array}{r}\text { Nitrog } \\
\text { nitrite }+\mathbf{n} \\
\text { dissol } \\
(\mathrm{mg} / \mathrm{L} \mathrm{a}\end{array}$ & $\begin{array}{l}\text { en, } \\
\text { trate, } \\
\text { ed } \\
\text { N) }\end{array}$ & $\begin{array}{l}\text { Nitrogen, } \\
\text { ammonia, } \\
\text { dissolved } \\
\text { (mg/L as } \mathrm{N} \text { ) }\end{array}$ & $\begin{array}{c}\text { Phosphorus, } \\
\text { ortho, } \\
\text { dissolved } \\
\text { (mg/L as P) }\end{array}$ \\
\hline Cherry Canyon seep & $09-18-01$ & 400 & 500 & 0.0 & & .11 & & 0.96 & $<.02$ \\
\hline & $05-02-02$ & --- & --- & $<.0$ & 06 & 1.4 & & $<.04$ & $<.02$ \\
\hline Walnut Canyon headquarters well & 09-20-01 & $<1$ & $<1$ & --- & & --- & & --- & --- \\
\hline Heiser Spring & $10-23-01$ & e7 & $<1$ & $<.0$ & 08 & 1.8 & & $<.04$ & $<.02$ \\
\hline & $05-03-02$ & $<1$ & $<1$ & $<.0$ & 08 & 1.7 & & $<.04$ & $<.02$ \\
\hline Little Colorado River & 09-13-02 & $\mathrm{e} 5,200 \mathrm{k}$ & $\mathrm{e} 10,000 \mathrm{k}$ & .0 & 2 & 1.0 & & $<.04$ & .05 \\
\hline
\end{tabular}


Table 3. U.S. Environmental Protection Agency Primary and Secondary Maximum Contaminant Levels (U.S. Environmental Protection Agency, 2002) for analyzed constituents in water samples from selected sites, Walnut Canyon and Wupatki National Monuments, Arizona, 2001-02

[Maximum Contaminant Levels (MCLs) are legally enforceable standards that apply to public water systems. MCLs protect public health by limiting the levels of contaminants in drinking water. Secondary Maximum Contaminant Levels (SMCLs) are non-enforceable guidelines regulating contaminants that may cause cosmetic effects (such as skin or tooth discoloration) or aesthetic effects (such as taste, odor, or color) in drinking water. ---, no standard; cols. per $100 \mathrm{~mL}$, colonies per 100 milliliters; $\mathrm{mg} / \mathrm{L}$, milligrams per liter; $\mu \mathrm{g} / \mathrm{L}$, micrograms per liter]

\begin{tabular}{|c|c|c|c|c|}
\hline Constituent & Units & MCL & SMCL & Remarks \\
\hline $\mathrm{pH}$ & $\begin{array}{l}\text { standard } \\
\text { units }\end{array}$ & --- & $6.5-8.5$ & SMCL is exceeded when $\mathrm{pH}$ is below 6.5 or above 8.5 \\
\hline Total coliform bacteria & $\begin{array}{l}\text { number of } \\
\text { samples }\end{array}$ & 1 & --- & $\begin{array}{l}\text { Not a health threat in itself; used to indicate whether } \\
\text { other potentially harmful bacteria are present }{ }^{1}\end{array}$ \\
\hline Fecal coliform bacteria & $\begin{array}{l}\text { number of } \\
\text { samples }\end{array}$ & 1 & --- & From human or animal fecal waste material ${ }^{1}$ \\
\hline Escherichia coli bacteria (E. coli) & $\begin{array}{l}\text { number of } \\
\text { samples }\end{array}$ & 1 & --- & From human or animal fecal waste material ${ }^{1}$ \\
\hline Sulfate & $\mathrm{mg} / \mathrm{L}$ & --- & 250 & \\
\hline Chloride & $\mathrm{mg} / \mathrm{L}$ & --- & 250 & \\
\hline Fluoride & $\mathrm{mg} / \mathrm{L}$ & 4 & 2 & \\
\hline Dissolved solids & $\mathrm{mg} / \mathrm{L}$ & --- & 500 & \\
\hline Nitrogen, nitrite & $\mathrm{mg} / \mathrm{L}$ & 1 & --- & \\
\hline Nitrogen, nitrite + nitrate & $\mathrm{mg} / \mathrm{L}$ & 10 & --- & \\
\hline Aluminum & $\mu \mathrm{g} / \mathrm{L}$ & --- & 50 to 200 & \\
\hline Antimony & $\mu \mathrm{g} / \mathrm{L}$ & 6 & --- & \\
\hline Arsenic & $\mu \mathrm{g} / \mathrm{L}$ & 10 & --- & \\
\hline Barium & $\mu \mathrm{g} / \mathrm{L}$ & 2,000 & --- & \\
\hline Beryllium & $\mu \mathrm{g} / \mathrm{L}$ & 4 & --- & \\
\hline Cadmium & $\mu \mathrm{g} / \mathrm{L}$ & 5 & --- & \\
\hline Chromium & $\mu \mathrm{g} / \mathrm{L}$ & 100 & --- & \\
\hline Copper & $\mu \mathrm{g} / \mathrm{L}$ & $\begin{array}{c}1,300 \\
\text { action level }\end{array}$ & 1,000 & $\begin{array}{l}\text { Regulated by a treatment technique that requires } \\
\text { systems to control the corrosiveness of water }\end{array}$ \\
\hline Iron & $\mu \mathrm{g} / \mathrm{L}$ & --- & 300 & \\
\hline Lead & $\mu \mathrm{g} / \mathrm{L}$ & $\begin{array}{c}15 \\
\text { action level }\end{array}$ & --- & $\begin{array}{l}\text { Regulated by a treatment technique that requires } \\
\text { systems to control the corrosiveness of water }\end{array}$ \\
\hline Manganese & $\mu \mathrm{g} / \mathrm{L}$ & --- & 50 & \\
\hline Silver & $\mu \mathrm{g} / \mathrm{L}$ & --- & 100 & \\
\hline Zinc & $\mu \mathrm{g} / \mathrm{L}$ & --- & 5,000 & \\
\hline Uranium & $\mu \mathrm{g} / \mathrm{L}$ & 30 & --- & \\
\hline
\end{tabular}

\footnotetext{
${ }_{2}^{1}$ Under the MCL standards for water systems from which fewer than 40 samples are collected per month, no more than one sample may be positive.
}

2 If more than 10 percent of water samples exceed the action level, water systems must take additional steps. 
The concentration of total coliform bacteria in Heiser Spring was higher in May 2002 (>8,000 cols. per $100 \mathrm{~mL})$ than in October 2001 (1,300 cols. per $100 \mathrm{~mL}$ ). The October 2001 water sample for Heiser Spring contained fecal coliform bacteria, and the May 2002 sample did not have fecal coliform.

Discharge from Cherry Canyon seep was too small to be measured, discharge in the Little Colorado River was too large to be measured, and natural discharge from Heiser Spring could not be measured because all water flow was into and out of an underground spring box. During the two visits to Heiser Spring, water was pumped out of the spring box and the rate of water flow (recovery) back into the spring box was measured. On October 23, 2001, the recovery rate was $0.50 \mathrm{gal} / \mathrm{min}$, and on May 3, 2002, the recovery rate was $0.48 \mathrm{gal} / \mathrm{min}$ (table 4 ).

Table 4. Discharge at selected sites, Walnut Canyon and Wupatki National Monuments, Arizona, 2001-02

$[<$, less than $]$

\begin{tabular}{lcc}
\hline \multicolumn{1}{c}{ Site name } & Date & $\begin{array}{c}\text { Discharge, } \\
\text { in gallons } \\
\text { per minute }\end{array}$ \\
\hline Cherry Canyon Seep & $09-18-01$ & $<0.05$ \\
Heiser Spring & $05-02-02$ & $<0.05$ \\
& $10-23-01$ & ${ }^{1} 0.48$ \\
& $05-03-02$ & ${ }^{1} 0.50$ \\
\hline
\end{tabular}

${ }^{1}$ Average recovery rate of flow into spring box. Water was pumped out of the box until about 1 inch remained in the bottom, and the volume of water that flowed back into the box was measured after 140 minutes. In October 2001, the average initial height of water in the box was 12.9 inches, and the initial volume of water was 180 gallons. In May 2003, the average initial height of water in the box was 10.8 inches, and the initial volume of water was 150 gallons.

\section{SUMMARY}

The USGS, in cooperation with the National Park Service, collected and analyzed water samples from four sites at Walnut Canyon and Wupatki National Monuments in north-central Arizona during September 2001 to September 2002. This inventory was part of a nationwide program of the National Park Service to obtain baseline water-quality information in national parks and monuments throughout the United States. The water-quality data and applicable U.S. Environmental Protection Agency Primary and Secondary Maximum Contaminant Levels are presented in this report.
Walnut Canyon National Monument is $5 \mathrm{mi}^{2}$ and ranges in altitude from 6,200 to $6,900 \mathrm{ft}$. Wupatki National Monument is $55 \mathrm{mi}^{2}$ and ranges in altitude from 4,300 to 5,700 ft. In Walnut Canyon, water samples were collected from Cherry Canyon seep in a shallow local aquifer and from the Walnut Canyon headquarters well in a deep regional aquifer. In Wupatki, water samples were collected from Heiser Spring in a shallow local aquifer and from the Little Colorado River, which has a 22,000 square-mile drainage area at the eastern boundary of the monument.

Water-quality samples were collected in September-October 2001 and May 2002 from Cherry Canyon seep in Walnut Canyon and Heiser Spring in Wupatki, in September-October 2001 from the Walnut Canyon headquarters well, and in September 2002 from the Little Colorado River. Several different types of constituents were determined from the samples depending on the site and the frequency of sampling.

Concentrations of dissolved solids were similar within the two monuments; the range for water samples from Walnut Canyon was 203 to $248 \mathrm{mg} / \mathrm{L}$, and the range for water samples from Wupatki was 503 to $614 \mathrm{mg} / \mathrm{L}$. Concentrations of trace elements were generally low in water from the three ground-water sites-Cherry Canyon seep, Walnut Canyon headquarters well, and Heiser Spring. The water sample collected from the Little Colorado River, however, had high concentrations of aluminum $(4,020 \mu \mathrm{g} / \mathrm{L})$, antimony $(54 \mu \mathrm{g} / \mathrm{L})$, arsenic $(14.3 \mu \mathrm{g} / \mathrm{L})$, and iron $(749 \mu \mathrm{g} / \mathrm{L})$ relative to U.S. Environmental Protection Agency MCLs and SMCLs.

Concentrations of nitrate (as nitrogen) in water samples from the four sites were generally low ( 0.11 to $1.8 \mathrm{mg} / \mathrm{L}$ ) and are within the upper 25 percent of nitrate concentrations in the regional aquifer near Flagstaff in 1996 and 1997. Water samples from Cherry Canyon seep, Heiser Spring, and the Little Colorado River contained total coliform bacteria. Fecal coliform and $E$. coli bacteria were found in water samples from Cherry Canyon seep and the Little Colorado River. Indicators of human or animal contamination differed in samples from Heiser Spring; one sample in October 2001 contained fecal coliform, and one sample in May 2002 did not contain fecal coliform or E. coli.

U.S. Environmental Protection Agency MCLs for antimony and arsenic were exceeded in the water sample from the Little Colorado River. SMCLs for $\mathrm{pH}$ (range), dissolved solids, sulfate, aluminum, iron, and manganese were exceeded in some of the samples from Cherry Canyon seep, Heiser Spring, and the Little Colorado River. 


\section{REFERENCES CITED}

Bills, D.J., Truini, Margot, Flynn, M.E., Pierce, H.A., Catchings, R.D., and Rymer, M.J., 2000, Hydrogeology of the regional aquifer near Flagstaff, Arizona, 1994-97: U.S. Geological Survey Water-Resources Investigations Report 00-4122, 143 p.

Britton, L.J., and Greeson, P.E., 1988, Methods for collection and analysis of aquatic biological and microbiological samples: U.S. Geological Survey Techniques of Water-Resources Investigations, book 5, chap. A4, 685 p.

Cosner, O.J., 1962, Ground water in the Wupatki and Sunset Crater National Monuments, Coconino County, Arizona: U.S. Geological Survey Water-Supply Paper 1475-J, p. 357-374.

Faires, L.M., 1993, Methods of analysis by the U.S. Geological Survey National Water Quality Laboratory-Determination of metals in water by inductively coupled plasma-mass spectrometry: U.S. Geological Survey Open-File Report 92-634, 28 p.

Fishman, M.J, 1993, Methods of analysis by the U.S. Geological Survey National Water Quality Laboratory- Determination of inorganic and organic constituents in water and fluvial sediments: U.S. Geological Survey Open-File Report 93-125, 217 p.

Fishman, M.J., and Friedman, L.C., eds., 1989, Methods for the determination of inorganic substances in water and fluvial sediments: U.S. Geological Survey Techniques of Water-Resources Investigations, book 5, chap. A1, $545 \mathrm{p}$.

Friedman, L.C., and Erdmann, D.E., 1982, Quality assurance practices for the chemical and biological analyses of water and fluvial sediments: U.S. Geological Survey Techniques of Water-Resources Investigations, book 5, chap. A6, $181 \mathrm{p}$.

Garbarino, J.R., 1999, Methods of analysis by the U.S. Geological Survey National Water Quality Laboratory-Determination of dissolved arsenic, boron, lithium, selenium, strontium, thallium, and vanadium using inductively coupled plasma-mass spectrometry: U.S. Geological Survey Open-File Report 99-093, 31 p.

Graf, J.B., Wirt, Laurie, Swanson, E.K., Fisk, G.G., and Gray, J.R., 1996, Streamflow transport of radionuclides and other chemical constituents in the Puerco and Little Colorado River Basins, Arizona and New Mexico: U.S. Geological Survey Water-Supply Paper 2459, 89 p.
Jones, S.R., and Garbarino, J.R., 1999, Methods of analysis by the U.S. Geological Survey National Water Quality Laboratory-Determination of arsenic and selenium in water and sediment using graphite furnace atomic absorption spectrometry: U.S. Geological Survey Open-File Report 98-639, 39 p.

Koterba, M.T., Wilde, F.D., and Lapham, W.W., 1995, Ground-water data-collection protocols and procedures for the National Water-Quality Assessment ProgramCollection and documentation of water-quality samples and related data: U.S. Geological Survey Open-File Report 95-399, 113 p.

McLain, B.J., 1993, Methods of analysis by the U.S. Geological Survey National Water Quality Laboratory-Determination of chromium in water by graphite furnace atomic absorption spectrophotometry: U.S. Geological Survey Open-File Report 93-449, $16 \mathrm{p}$.

Myers, D.N., and Wilde, F.D., eds., 1999, National field manual for the collection of water-quality dataBiological indicators: U.S. Geological Survey Techniques of Water-Resources Investigations, book 9, chap. A7, v.p.

Pope, G.L., Rigas, P.D., and Smith, C.F., 1998, Statistical summaries of streamflow data and characteristics of drainage basins for selected streamflow-gaging stations in Arizona through water year 1996: U.S. Geological Survey Water-Resources Investigations Report 98-4225, 907 p.

Struzeski, T.M., DeGiacoma, W.J., and Zayhowski, E.J., 1996, Methods of analysis by the U.S. Geological Survey National Water Quality LaboratoryDetermination of dissolved aluminum and boron in water by inductively coupled plasma-atomic emission spectrometry: U.S. Geological Survey Open-File Report 96-149, 17 p.

U.S. Department of Agriculture, Natural Resources Conservation Service, 1999, Arizona annual precipitation: Fort Worth, Texas, USDA-NRCS National Cartography \& Geospatial Center, scale 1:1,300,000.

U.S. Environmental Protection Agency, 2002, Current drinking water standards, national primary and secondary drinking water regulations: Washington, D.C., U.S. Environmental Protection Agency, accessed October 16, 2002, at URL http://www.epa.gov/safewater/mcl.html.

U.S. Geological Survey, 1999, The quality of our nation's waters-Nutrients and pesticides: U.S. Geological Survey Circular 1225, 82 p. 
Western Regional Climate Center, Desert Research Institute, 2002, Arizona climate summaries: Reno, Nevada, Western Regional Climate Center, Desert Research Institute, accessed October 3, 2002, at URL http://www.wrcc.dri.edu/summary/climsmaz.html.

Wilde, F.D., and Radtke, D.B., eds., 1998, National field manual for the collection of water-quality data-Field measurements: U.S. Geological Survey Techniques of Water-Resources Investigations, book 9, chap. A6, v.p.

Wilde, F.D., Radtke, D.B., Gibs, Jacob, and Iwatsuybo, R.T., 1998a, National field manual for the collection of water-quality data-Preparations for water sampling: U.S. Geological Survey Techniques of Water-Resources Investigations, book 9, chap. A1, 38 p. 1998b, National field manual for the collection of water-quality data-Selection of equipment for water sampling: U.S. Geological Survey Techniques of Water-Resources Investigations, book 9, chap. A2, 82 p. 1998c, National field manual for the collection of water-quality data-Cleaning of equipment for water sampling: U.S. Geological Survey Techniques of Water-Resources Investigations, book 9, chap. A3, 65 p. 1999, National field manual for the collection of water-quality data-Collection of water samples: U.S. Geological Survey Techniques of Water-Resources Investigations, book 9, chap. A4, 103 p. 